\title{
An ENVIRONMENTAL ASSESSMENT OF CATTLE MANURE AND UREA FERTILIZER TREATMENTS FOR CORN PRODUCTION IN THE NORTHERN GREAT PLAINS
}

\author{
C. Alan Rotz ${ }^{1, *}$, Senorpe Asem-Hiablie ${ }^{1}$, Erin Cortus ${ }^{2}$, \\ Mindy Spiehs ${ }^{3}$, Shafiqur Rahman ${ }^{4}$, Anne Stoner ${ }^{5}$ \\ ${ }^{1}$ USDA-ARS Pasture Systems and Watershed Management Research Unit, University Park, Pennsylvania, USA. \\ ${ }^{2}$ Department of Bioproducts and Biosystems Engineering, University of Minnesota, St. Paul, Minnesota, USA. \\ ${ }^{3}$ USDA-ARS U.S. Meat Animal Research Center, Clay Center, Nebraska, USA. \\ ${ }^{4}$ Department of Agricultural and Biosystems Engineering, North Dakota State University, Fargo, North Dakota, USA. \\ ${ }^{5}$ Climate Center, Texas Tech University, Lubbock, Texas, USA. \\ *Correspondence: al.rotz@usda.gov.
}

\section{HighLIGHTS}

- The Integrated Farm System Model appropriately represented average emission rates measured in corn production.

- Compared to the use of feedlot manure, application of bedded pack manure generally increased N and P losses.

- Compared to inorganic fertilizer use, cattle manure increased soluble P loss while reducing GHG emission.

- Production and environmental differences among production systems were similar under recent and future climates.

ABSTRACT. Nitrogen (N), phosphorus (P), and carbon (C) emissions from livestock systems have become important regional, national, and international concerns. Our objective was to use process-level simulation to explore differences among manure and inorganic fertilizer treatments in a corn production system used to feed finishing cattle in the Northern Great Plains region of the U.S. Our analysis included model assessment, simulation to compare treatments under recent climate, and comparisons using projected midcentury climate. The Integrated Farm System Model was evaluated in representing the performance and nutrient losses of corn production using cattle manure without bedding, manure with bedding, urea, and no fertilization treatments. Two-year field experiments conducted near Clay Center, Nebraska; Brookings, South Dakota; and Fargo, North Dakota provided observed emission data following these treatments. Means of simulated emission rates of methane, ammonia, and nitrous oxide were generally similar to those observed from field-applied manure or urea fertilizer. Simulation of corn production systems over 25 years of recent climate showed greater soluble P runoff with use of feedlot and bedded manure compared to use of inorganic fertilizers, but life-cycle fossil energy use and greenhouse gas emission were decreased. Compared to feedlot manure, application of bedded pack manure generally increased $N$ and $P$ losses in corn production by retaining more $N$ in manure removed from a bedded housing facility and through increased runoff because a large portion of the stover was removed from the cornfield for use as bedding material. Simulation of these treatments using projected midcentury climate indicated a trend toward a small increase in simulated grain production in the Dakotas and a small decrease for irrigated corn in Nebraska. Climate differences affected the three production systems similarly, so production and environmental impact differences among the fertilization systems under future climate were similar to those obtained under recent climate.

Keywords. Climate change, Greenhouse gas, Integrated Farm System Model, Nutrient losses.

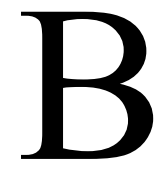

eef cattle production is a major agricultural industry in the Northern Great Plains region of the U.S. About 5.6 million cattle are finished each year in the three states of Nebraska, South Dakota, and

The authors have paid for open access for this article. This work is licensed under a Creative Commons AttributionNonCommercial-NoDerivatives 4.0 International License https://creative commons.org/licenses/by-nc-nd/4.0/

Submitted for review on 24 August 2020 as manuscript number NRES 14275; approved for publication as a Research Article by the Natural Resources \& Environmental Systems Community of ASABE on 20 April 2021.

Mention of company or trade names is for description only and does not imply endorsement by the USDA. The USDA is an equal opportunity provider and employer.
}

North Dakota (USDA-NASS, 2019; Rotz et al., 2019). Most of the cattle are finished on open feedlots, but various types of enclosed housing or barns are also used on smaller operations, particularly in the Dakotas (Asem-Hiablie et al., 2016). Although these enclosures increase the investment in facilities, they may provide better control over manure handling and nutrient losses to the environment.

Most manure is applied to cropland to recycle nutrients where nitrogen $(\mathrm{N})$, phosphorus $(\mathrm{P})$, and carbon $(\mathrm{C})$ losses occur. The manure may come directly from the lot or other housing facility, or it may be stored or composted prior to field application. Following field application, varying amounts of nutrient losses can occur. The amount lost depends on the application method, the characteristics of the 
manure, and the time the manure remains on the surface prior to incorporation by tillage (Rotz, 2004). Losses in the form of ammonia $\left(\mathrm{NH}_{3}\right)$ can be high when manure is surfaceapplied without incorporation (Rotz et al., 2014). For manure removed from feedlots, most volatile compounds such as $\mathrm{NH}_{3}$ have been lost prior to application (Todd et al., 2011), so field emissions are less. Following incorporation, the rate, depth, and timing of application further influence field losses and nutrient use (IPNI, 2012).

To improve the environmental sustainability of feeding cattle, nutrient losses must be reduced to recycle more manure nutrients through feed production. This can improve profitability for the producer by reducing the need for inorganic fertilizer while reducing potential damage to the environment. A systems approach considering all important components is needed to assess and improve nutrient cycling in cattle feeding systems. The Integrated Farm System Model (IFSM) provides a tool for performing a comprehensive assessment of the nutrient losses from production systems along with other environmental impacts (Rotz et al., 2018). By simulating and comparing alternative systems, environmental improvements can be quantified along with performance and economic measures.

Experiments have been conducted in North Dakota (Mehata et al., 2019), South Dakota (Niraula et al., 2019), and Nebraska (Spiehs et al., 2020) to measure methane $\left(\mathrm{CH}_{4}\right)$, $\mathrm{NH}_{3}$, and nitrous oxide $\left(\mathrm{N}_{2} \mathrm{O}\right)$ emissions following four fertilization treatments in corn (Zea mays L.) production. Fertilization treatments were cattle manure, cattle manure with bedding, urea fertilizer, and no fertilization. Emissions varied across the three locations, but differences between the use of manure and urea fertilizer were small.

Our objectives were to (1) compare observed and simulated emissions following these fertilization treatments to show that the IFSM could represent these systems, and (2) simulate corn production systems in the Northern Great Plains region to compare the performance and environmental impacts of the alternative fertilization practices under recent and projected midcentury climates.

\section{MATERIALS AND MeTHODS}

Our analysis involved a series of simulations of corn grain production. The first step was to compare emissions predicted by the model to data measured in the field experiments conducted in North Dakota, South Dakota, and Nebraska. The model was then used to simulate corn production systems in these states using 25 years of recent weather. Finally, production systems were simulated using projected climate data to evaluate potential future climate effects on performance and environmental impacts.

\section{INTEGRATED FARM SYSTEM MODEL}

Corn production and manure management strategies were simulated using the IFSM, a software tool developed to assess and compare the environmental and economic sustainability of crop, dairy, and beef cattle production systems (USDA-ARS, 2020). The model simulates crop production, feed use, and the return of manure nutrients back to the land for up to 25 years of daily weather. Daily growth and development of crops are predicted based on soil water and $\mathrm{N}$ availability, ambient temperature, and solar radiation (Rotz et al., 2018). Simulated tillage, planting, and harvest operations predict resource use, timeliness of operations, crop losses, and nutritive quality of feeds produced.

Nutrient flows are tracked to predict losses to the environment and potential accumulation in the soil (Rotz et al., 2018). For crop-producing farms, nutrient losses include those associated with the processes of volatilization, nitrification, denitrification and leaching of $\mathrm{N}$, erosion of sediment, and runoff of sediment-bound and dissolved $\mathrm{P}$ across the farm boundaries. Whole-system mass balances of $\mathrm{N}, \mathrm{P}$, and $\mathrm{C}$ are determined as the sum of nutrient imports in manure, fertilizer, deposition, and fixation, minus the nutrient exports in losses and feeds produced.

Simulation of a production system provides the direct emissions and resources used each year. A farm-gate life cycle assessment determines the annual intensities of $\mathrm{C}$ emissions and energy use in producing the feed (Rotz et al., 2018). Carbon dioxide $\left(\mathrm{CO}_{2}\right), \mathrm{CH}_{4}$, and $\mathrm{N}_{2} \mathrm{O}$ emissions from soil (as influenced by manure and fertilizer application), crop, and machinery sources and sinks, along with those from the production of resources used and indirect emissions resulting from $\mathrm{N}$ losses, are tracked to predict net greenhouse gas emission in $\mathrm{CO}_{2}$ equivalent $\left(\mathrm{CO}_{2} \mathrm{e}\right)$ units. The life cycle assessment includes upstream sources that occur in producing the resources used in the production system, including fuel, electricity, fertilizer, machinery, seed, and pesticides. Anthropogenic $\mathrm{C}$ emissions include those released through fossil fuel combustion and the decomposition of lime and urea fertilizer (IPCC, 2006). All fossil energy used on the farm, along with that used to produce the resources used, is accounted for to determine the total energy input. Intensities are determined as the total of direct, indirect, and upstream sources divided by the feed dry matter produced.

Components of the IFSM have been evaluated in previous studies to ensure reasonable predictions of system performance and environmental impacts. These evaluations have included grain crop production (Rotz et al. 2002), $\mathrm{NH}_{3}$ emission (Rotz et al., 2014), $\mathrm{N}_{2} \mathrm{O}$ emission (Chianese et al., 2009b), $\mathrm{CH}_{4}$ emission (Chianese et al., 2009c), and P losses (Sederovich et al., 2007). Other studies have included farmscale evaluations of production and environmental impacts (Belflower et al., 2012; Rotz et al., 2011, 2013, 2016). For the current study, comparison to field observations was done to assess the model's ability to represent fertilization treatment effects on several environmental impacts of corn production in the Northern Great Plains region.

\section{SimUlation OF FiELd EXPERIMENTS}

The IFSM was set up to represent field experiments previously conducted near Clay Center, Nebraska; Brookings, South Dakota; and Fargo, North Dakota to measure $\mathrm{NH}_{3}$ and greenhouse gas $\left(\mathrm{CH}_{4}, \mathrm{CO}_{2}, \mathrm{~N}_{2} \mathrm{O}\right)$ emissions following field application of manure or inorganic fertilizer (Niraula et al., 2018; Mehata et al., 2019; Spiehs et al., 2020). Two-year field studies examined the influence of land application of solid beef manure and solid beef manure with bedding on the emissions of $\mathrm{N}_{2} \mathrm{O}, \mathrm{CH}_{4}$, and $\mathrm{NH}_{3}$, along with corn whole- 
plant yield and plant tissue $\mathrm{N}$ content. Wheat straw bedding was used in the North Dakota trial, and corn stover bedding was used in the other trials. In the field trials, available manure $\mathrm{N}$ following incorporation was estimated assuming $95 \%$ availability of ammonium N, $50 \%$ availability of organic $\mathrm{N}$, and $25 \%$ availability of the previous year's applied organic N (Niraula et al., 2018). In addition, treatments of urea fertilizer and no fertilizer were compared with the manure treatments. In North Dakota, treatments were applied to Fargo-Ryan silty clay soil. Based on initial soil nutrient tests prior to fertilization, $\mathrm{N}$ was applied in the field trials at rates of 220 and $109 \mathrm{~kg} \mathrm{ha}^{-1}$ in years 1 and 2, respectively, using manure or urea fertilizer to meet the corn $\mathrm{N}$ demand and yield goal of $10,760 \mathrm{~kg} \mathrm{ha}^{-1}\left(160 \mathrm{bu} \mathrm{acre}^{-1}\right)$ (table 1). The same treatments were applied in South Dakota on a silty clay loam soil, classified as a Udic Haploborolls. At this location, $\mathrm{N}$ was applied at rates of $130 \mathrm{~kg} \mathrm{ha}^{-1}$ for both manure and urea treatments in year 1 and $184 \mathrm{~kg} \mathrm{ha}^{-1}$ in year 2 with a yield goal of $11,300 \mathrm{~kg} \mathrm{ha}^{-1}\left(180 \mathrm{bu} \mathrm{acre}^{-1}\right)$. In Nebraska, the soil was a loess silt loam. Nitrogen was applied at a rate 291 $\mathrm{kg} \mathrm{ha}^{-1}$ in both years with a $15,000 \mathrm{~kg} \mathrm{ha}^{-1}\left(240 \mathrm{bu} \mathrm{acre}^{-1}\right)$ yield goal. Dry land farming was used in the Dakotas, while irrigation was used in the Nebraska trials (table 1).

Nitrous oxide and $\mathrm{CH}_{4}$ fluxes were measured from soil surfaces using static chambers constructed of polyvinyl chloride (PVC) as recommended in the GRACEnet project protocol (Parkin and Venterea, 2010). Three PVC anchor rings were inserted into each plot and spaced at approximately equal distances from the center (Niraula et al., 2018). Headspace air sampling was done during 09:00 to 12:00 local time because the surface soil temperature was near its daily average during this time. At the North Dakota and Nebraska sites, headspace air samples were collected on about $7 \mathrm{~d}$ intervals throughout the 2016 and 2017 growing seasons, with more frequent sampling for the few weeks following planting. The sampling frequency for South Dakota was two to three times in the two weeks before planting and two weeks after planting and monthly throughout the growing season. Headspace air samples were analyzed for $\mathrm{N}_{2} \mathrm{O}$ and $\mathrm{CH}_{4}$ within two days using a gas chromatograph. Daily flux from each of the three sampling points within a plot was determined from concentrations relative to elapsed time. Evaluated fluxes were then converted from volumetric basis to mass basis using the modified ideal gas law.

Ammonia volatilization from each of four replicated plots was measured using semi-static open chambers with three chambers per plot (Niraula et al., 2018). Measurements were made over periods of normally two weeks. The chambers, consisting of a $2 \mathrm{~L}$ bottle and polyfoam strips dipped in $\mathrm{H}_{3} \mathrm{PO}_{4}$ solution, were secured in an upright position on the soil surface. At the end of each period, samples were collected and analyzed using an automated ammonia analyzer. The volatilization loss from each plot was determined as the average of the three chambers. An average emission rate $\left(\mathrm{g} \mathrm{ha}^{-1} \mathrm{~h}^{-1}\right)$ was determined by dividing the measured emission by the measurement period.

Chamber-based flux measurements are known to influence the flux conditions at the soil surface by reducing air movement, which leads to underestimation of flux (Venterea, 2010; Niraula et al. 2019). A theoretical flux underestimation method (Venterea, 2010) was applied to the $\mathrm{N}_{2} \mathrm{O}$ flux estimates to adjust for soil and weather conditions, but $\mathrm{CH}_{4}$ flux was reported without further adjustment (Niraula et al., 2019; Mehata et al., 2019). Flux calculation performance is sensitive to multiple variables that can vary widely in field conditions and interact to affect measurement error (Venterea et al., 2020). Considering these variables, a maximum error of $20 \%$ was considered for any one concentration measurement in time.

Each treatment was simulated as a small field (10 ha) using the IFSM where manure or urea fertilizer was incorporated into the soil immediately or within a few hours of application to represent the actual conditions (fig. 1). Model parameters were set to generally represent the management of the treatments, including manure or fertilizer application amounts, corn variety, and planting and harvest dates. Soil characteristics were set to represent those of the location, and simulations were done using 2016 and 2017 daily weather data recorded at each location.

Our goal was to represent these production strategies with minimal changes or calibration of the model. This was not intended to be an evaluation of the model but rather

Table 1. Summary characteristics of field experiments conducted in three states of the U.S. Northern Great Plains.

\begin{tabular}{|c|c|c|c|c|c|c|c|c|}
\hline $\begin{array}{l}\text { State, Soil Type, } \\
\text { and Year }\end{array}$ & $\begin{array}{c}\text { Measurement } \\
\text { Period }^{[\mathrm{a}]}\end{array}$ & $\begin{array}{c}\text { Data } \\
\text { Points }\end{array}$ & $\begin{array}{c}\text { Mean Ambient } \\
\text { Temperature } \\
\left({ }^{\circ} \mathrm{C}\right)\end{array}$ & $\begin{array}{l}\text { Precipitation } \\
(\mathrm{mm})\end{array}$ & $\begin{array}{l}\text { Annual } \\
\text { Irrigation } \\
(\mathrm{mm})\end{array}$ & $\begin{array}{c}\text { Fertilized } \\
\text { Corn Yield } \\
\left(\mathrm{kg} \mathrm{DM} \mathrm{ha}^{-1}\right)\end{array}$ & $\begin{array}{c}\mathrm{N} \\
\text { Applied }^{[\mathrm{b}]} \\
\left(\mathrm{kg} \mathrm{ha}^{-1}\right) \\
\end{array}$ & $\begin{array}{c}\text { Initial } \\
\text { Soil N } \\
\left(\mathrm{kg} \mathrm{ha}^{-1}\right)\end{array}$ \\
\hline \multicolumn{9}{|c|}{ North Dakota: Fargo Ryan silty clay (Mehata et al., 2019) } \\
\hline Year 1 & $\begin{array}{c}14 \text { to } 29 \text { Oct. } 2015 \\
2 \text { May to } 2 \text { Aug. } 2016\end{array}$ & $\begin{array}{c}4 \\
13\end{array}$ & $\begin{array}{c}8.8 \\
19.5\end{array}$ & $\begin{array}{l}29.1 \\
259\end{array}$ & 0 & 8.0 & 220 & 23 \\
\hline Year 2 & $\begin{array}{l}16 \text { Oct. to } 11 \text { Nov. } 2016 \\
5 \text { May to } 22 \text { Aug. } 2017\end{array}$ & $\begin{array}{c}4 \\
13 \\
\end{array}$ & $\begin{array}{c}8.8 \\
19.0 \\
\end{array}$ & $\begin{array}{l}45.0 \\
174 \\
\end{array}$ & 0 & 6.5 & 220 & 57 \\
\hline \multicolumn{9}{|c|}{ South Dakota: Silty clay loam (Niraula et al., 2019) } \\
\hline Year 1 & $\begin{array}{c}6 \text { to } 16 \text { Nov. } 2015 \\
24 \text { Apr. to } 2 \text { Aug. } 2016\end{array}$ & $\begin{array}{l}3 \\
5\end{array}$ & $\begin{array}{c}5.5 \\
18.7\end{array}$ & $\begin{array}{l}17.1 \\
344\end{array}$ & 0 & 10.0 & 130 & 113 \\
\hline Year 2 & $\begin{array}{l}17 \text { Nov. to } 1 \text { Dec. } 2016 \\
25 \text { Apr. to } 10 \text { Aug. } 2017\end{array}$ & $\begin{array}{l}3 \\
4 \\
\end{array}$ & $\begin{array}{c}0.5 \\
18.1 \\
\end{array}$ & $\begin{array}{l}27.7 \\
259 \\
\end{array}$ & 0 & - & 183 & 58 \\
\hline \multicolumn{9}{|c|}{ Nebraska: Loess silt loam (Spiehs et al., 2020) } \\
\hline Year 1 & $\begin{array}{l}4 \text { to } 24 \text { Nov. } 2015 \\
13 \text { Apr. to } 10 \text { Oct. } 2016\end{array}$ & $\begin{array}{c}5 \\
13\end{array}$ & $\begin{array}{c}6.5 \\
20.0\end{array}$ & $\begin{array}{r}43.2 \\
540\end{array}$ & 238 & 12.4 & 291 & 14 \\
\hline Year 2 & $\begin{array}{c}1 \text { to } 29 \text { Nov. } 2016 \\
25 \text { Apr. to } 24 \text { Oct. } 2017\end{array}$ & $\begin{array}{c}5 \\
15\end{array}$ & $\begin{array}{c}6.6 \\
19.2\end{array}$ & $\begin{array}{r}25.8 \\
644\end{array}$ & 61 & 12.7 & 291 & 9 \\
\hline
\end{tabular}

[a] Treatments were applied just before the first day of the fall measurement period for all treatments, except urea fertilizer was applied just before the spring measurement period in the North Dakota trial.

[b] "N applied" represents the available $\mathrm{N}$ in applied manure and the $\mathrm{N}$ applied in urea fertilizer. 


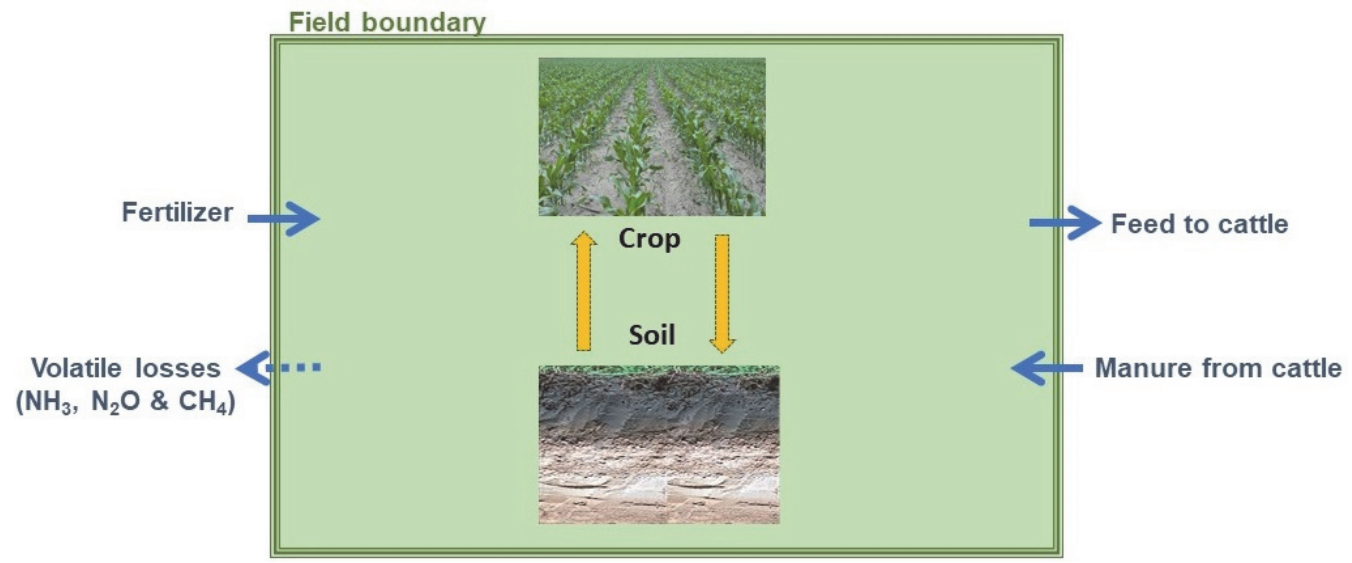

Figure 1. Processes and nutrient flows simulated in IFSM to assess the prediction of volatile losses measured in field plot experiments.

a demonstration that the model could represent these production strategies and the associated emissions. Model adjustments included setting the initial soil $\mathrm{N}$ level before treatment application to represent that observed (table 2), and initial soil moisture was set at $50 \%$ of available water-holding capacity to represent fall levels expected in this region. Simulated daily emission rates of $\mathrm{NH}_{3}, \mathrm{CH}_{4}$, and $\mathrm{N}_{2} \mathrm{O}\left(\mathrm{g} \mathrm{ha}^{-1} \mathrm{~h}^{-1}\right)$ on each observation date were compared to those observed. A two-sample t-test assuming equal variances was used for statistical comparison, where a low probability $(p<0.01)$ indicated that observed and simulated data were different. For both observed and simulated data, standard deviations were similar to the mean in magnitude.

\section{Simulated Production Systems}

Following model assessment, full corn production systems were simulated with the IFSM to compare longer-term performance and environmental impacts of alternative fertilization strategies. These simulations included all processes related to manure application, crop establishment, and harvest along with crop growth and soil processes (fig. 2). Two of the systems represented corn production using manure obtained from cattle finishing operations, and a third produced corn using urea fertilizer. The manure systems used (1) manure from a traditional open lot with relatively dry solid manure removed after each cycle of cattle and (2) manure from a bedded pack barn with bedded manure removed after each cycle of cattle.

For this series of simulations, the model parameters were set to represent farm practices in the region. The model was used without setting the conditions of the experiments (initial soil $\mathrm{N}$ and application rates and dates) because that was no longer relevant. Farm practices were similar to the strategies used in the field experiments, but some adjustments were made. The simulation was set to incorporate the manure the same day of application, but several hours between manure spreading and incorporation were allowed to better represent farm practices. In contrast to the field experiments, this allowed some time for $\mathrm{NH}_{3}$ volatilization and minor amounts of $\mathrm{CH}_{4}$ volatilization to occur prior to incorporation, as influenced by temperature, wind speed, and other factors. In these simulations, manure application and tillage operations occurred over a period of days, as influenced by weather and soil conditions. Because of these differences, the field-measured data do not apply directly to the multiyear simulations of the corn production systems. The processbased simulation represents these changes to predict their influence on emissions.

Corn production systems were sized to produce the grain needed to finish 2,000 cattle per year in two 5-month cycles. Crop area was set to provide enough grain to meet the average annual feed needs of the operation. Because yields

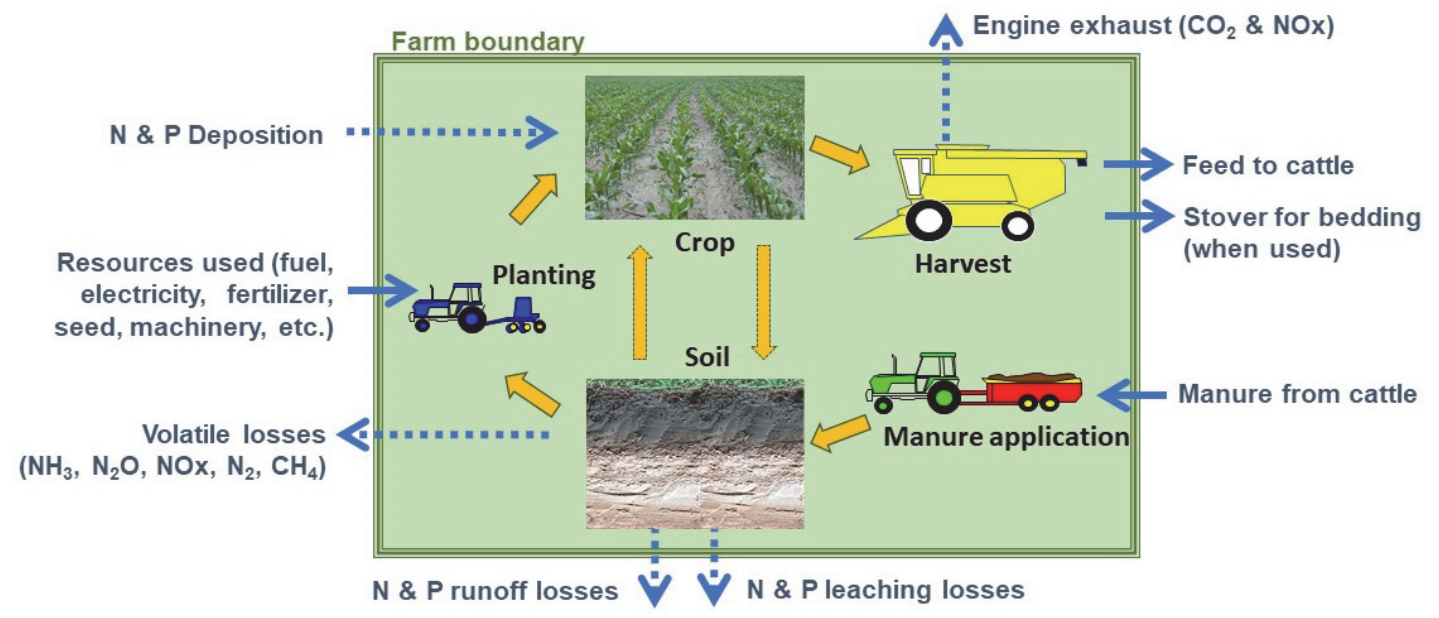

Figure 2. Processes and nutrient flows simulated in IFSM to evaluate and compare fertilization options on corn-producing farms. 
varied across locations, land area varied, with 342 ha in North Dakota, 275 ha in South Dakota, and 163 ha in Nebraska. The manure produced by these cattle was applied to the cropland to produce the feed. The soil characteristics for each location were those used in the field experiment simulations. Dry land production was used in the Dakotas, and irrigation was used as needed in Nebraska to prevent water stress effects on crop growth.

To obtain the quantity and nutrient content of the applied manure, separate simulations were performed for finishing 2,000 cattle at each location using the feed produced. Simulations were done using an open lot and a covered bedded pack structure. Because the manure characteristics varied among simulated years, 25-year average values were used as input to the corn crop simulation. There were minor variations across locations, but feedlot manure production was about 910 t DM per year, containing $2.7 \% \mathrm{~N}$ (90\% organic) and $0.75 \%$ P. For the bedded pack system, about 1700 t DM was produced, containing $1.8 \% \mathrm{~N}(80 \%$ organic $)$ and $0.4 \% \mathrm{P}$.

For these farm-scale simulations, manure from the cattle fed did not meet the $\mathrm{N}$ needs of the crop. In addition, applying greater amounts of manure would greatly exceed the crops need for P. Therefore, inorganic fertilizer was used, with the average annual application rate set to meet crop nutrient needs beyond that obtained from manure. Nitrogen needs were determined by maintaining a balance over all simulated years, with that applied equal to that removed in the crop plus that lost to the environment while maintaining crop yield. Supplemental N needs were met using urea applied at rates of $35 \mathrm{~kg} \mathrm{~N} \mathrm{ha}^{-1}$ with feedlot manure and $20 \mathrm{~kg} \mathrm{~N} \mathrm{ha}^{-1}$ with bedded manure in the Dakotas, and 88 and $80 \mathrm{~kg} \mathrm{~N} \mathrm{ha}^{-1}$ for feedlot and bedded manure, respectively, for the irrigated corn in Nebraska. This provided total $\mathrm{N}$ application rates of 130 and $140 \mathrm{~kg} \mathrm{~N} \mathrm{ha}^{-1}$ for feedlot and bedded manure in the Dakotas and 235 and $275 \mathrm{~kg} \mathrm{~N} \mathrm{ha}^{-1}$ in $\mathrm{Ne}-$ braska. With the recycling of manure nutrients back to the corn land, no $\mathrm{P}_{2} \mathrm{O}_{5}$ and $\mathrm{K}_{2} \mathrm{O}$ fertilizers were needed for the manure treatments. For the inorganic fertilizer treatment, $\mathrm{N}$, phosphate $\left(\mathrm{P}_{2} \mathrm{O}_{5}\right)$, and potash $\left(\mathrm{K}_{2} \mathrm{O}\right)$ needs were about 140 , 45 , and $30 \mathrm{~kg} \mathrm{ha}^{-1}$, respectively, in the Dakotas and 260, 76, and $53 \mathrm{~kg} \mathrm{ha}^{-1}$, respectively, in Nebraska. All inorganic $\mathrm{N}$ fertilizer was in the form of urea.

Appropriate machinery was used to simulate timely planting and harvest of crops. Tillage used to establish the corn included a disk operation followed by two field cultivator operations prior to planting. The earliest planting date varied with location from on or after April 18 in Nebraska to May 10 in North Dakota. The earliest corn harvest dates were the same for all locations, with grain harvest beginning on or after October 20. A corn variety from a greater maturity group was used in Nebraska.

Manure handling methods were similar between the manure treatments. When representing open lot systems, relatively dry manure (70\% DM) was handled and applied. With the use of bedded pack housing, manure was handled as a solid with a dry matter content of $32 \%$. Corn stover, harvested on the farm following grain harvest, was used for bedding at a rate of $4.0 \mathrm{~kg} \mathrm{~d}^{-1}$ per animal. The stover was harvested and handled using a large round bale system. All manure was surface-applied and incorporated by tillage on the day of application. Manure application occurred prior to planting in the spring and following harvest in the fall, where simulated dates varied with soil and weather conditions.

\section{Projected Climate Simulations}

All production systems were simulated using weather data for Carrington, North Dakota; Watertown, South Dakota; and Grand Island, Nebraska. Weather data were obtained by downscaling climate projections from nine global climate models (GCMs), including: Community Climate System Model 4, Centre National de Recherches Meteorologiques Circulation Model 5, Commonwealth Scientific and Industrial Research Organization Mark 3, Hadley Centre Global Environment Model 2 CC, Institute for Numerical Mathematics Climate Model 4, Institut Pierre Simon Laplace Coupled Model 5A LR, Model for Interdisciplinary Research on Climate 5, Max-Planck Institute Earth System Model LR, and Meteorological Research Institute Coupled Global Climate Model 3. The GCM projections of temperature, precipitation, and solar radiation were translated into high-resolution projections using the statistical Asynchronous Regional Regression Model (ARRM; Stoner et al., 2013). Weather data used were recent (1990-2015) and projected climate for midcentury (2040-2065). Future climate projections used a representative concentration pathway (RCP) of 8.5, which represents a "business as usual" use of fossil fuels and $\mathrm{C}$ emissions through midcentury. This represents a worst-case scenario for future weather patterns but is not unrealistic considering current trends.

For the midcentury simulations, a few management changes were made to adapt the production systems to the projected warmer climate. The maturity group for the corn variety was increased at each location to allow more growing degree-days to reach maturity. Planting and harvest dates were moved up by about one week to provide an earlier growing season of similar length with warmer growing conditions. Crop areas remained the same, so any change in yield was reflected in total grain production. All other characteristics of the operations were the same as those used in the base simulations.

Ambient temperature, precipitation, and measures of environmental impact were compared using the GLIMMIX procedure for generalized linear mixed models in SAS (SAS Institute, Cary, N.C.). A three-way analysis of variance was used to determine the effects and interactions across the three fertilization treatments (open lot manure, bedded pack manure, and urea fertilizer), three locations, and two climates (recent and midcentury). Predictions using the nine GCMs provided nine replicate measures of each environmental impact for each treatment. Differences among means and their interactions across fertilization treatments, locations, and climates were determined using a Tukey test $(\mathrm{p}<0.05)$.

\section{RESULTS AND DisCUSSION \\ SIMULATION OF FIELD EXPERIMENTS}

Methane emissions from cropland are normally negligible, with a potential for a small absorption (Chianese et al., 
2009a). A minor release of any $\mathrm{CH}_{4}$ remaining in the manure may occur when manure is broadcast on the soil surface. The emission data measured in the Dakotas were consistent with this general trend, but measurable amounts were observed in Nebraska, even when no manure was applied (table 2). This emission cannot be explained, but this was a small and unimportant source of methane emission compared to that found for cattle production systems (Rotz et al., 2013).

Observed $\mathrm{NH}_{3}$ emissions were greater in North Dakota than the other two locations (table 2). Factors that influence this difference could include the depth and completeness of incorporation, soil temperature, soil $\mathrm{pH}$ and the form of $\mathrm{N}$ applied (Rotz et al., 2014). The model was able to represent the $\mathrm{NH}_{3}$ emissions from manure treatments well in the Dakotas with an overestimate in Nebraska (table 2). Although the prediction in Nebraska was around twice that observed, these emission levels are small compared to other farm sources and thus relatively similar from a whole-farm perspective (Rotz et al., 2014). Averaged over all locations, simulated and observed $\mathrm{NH}_{3}$ emissions from manure treatments were similar (table 2).

For the urea fertilizer treatment, the model represented observed data well in North Dakota, but was greater than observed in South Dakota and Nebraska. Urea was applied in the spring in North Dakota and in the fall for the other locations. This implies that the model may overestimate $\mathrm{NH}_{3}$ emission during winter conditions. The relationship used in IFSM to predict soil emission of $\mathrm{NH}_{3}$ is a function of soil temperature, but it may provide a conservative estimate over winter conditions. In our further multiyear simulations, we assumed all urea fertilizer was applied in the spring, so this potential problem with $\mathrm{NH}_{3}$ emission would not apply. Ammonia loss from urea fertilized fields is normally considered to be about $15 \%$ of the applied N (Battye et al., 1994), and model predictions were consistent with this normal.

The model underpredicted $\mathrm{NH}_{3}$ emission for the unfertilized treatment in North Dakota. The average emission of $5.7 \mathrm{~g} \mathrm{NH}_{3} \mathrm{ha}^{-1} \mathrm{~h}^{-1}$ seems high compared to the initial soil $\mathrm{N}$ content (table 1). This implies that most of the observed initial soil $\mathrm{N}$ would be lost in the form of $\mathrm{NH}_{3}$ over the growing season or that the model is not properly representing transformation processes of the soil organic $\mathrm{N}$ pool under this condition of very low available soil N. Because the model represented this emission well at the other locations, measurement error was also a possibility. Use of no $\mathrm{N}$ fertilization was an infeasible option in our simulation of full corn production systems, so this potential problem in representing very low $\mathrm{N}$ availability under certain conditions was not considered a concern in our further analysis.

Observed $\mathrm{N}_{2} \mathrm{O}$ emission rates were similar across locations (table 2). Although not significant, the model tended to overestimate emission rates in North Dakota and underestimate those observed in Nebraska. The model is sensitive to the clay content of soils, which led to the greater values in North Dakota and lower values in Nebraska. Although denitrification losses are known to be influenced by soil clay content (Malique et al., 2019), this was not reflected in these observed data. Averaged over all locations, the model represented the observed emission rates of $\mathrm{N}_{2} \mathrm{O}$ well (table 2).

\section{Production Systems with Recent Climate}

The simulated corn-producing farms using each fertilization treatment and the resulting environmental impacts were first evaluated using recent climate. Similar comparisons among fertilization treatments were found across the three locations. Because land areas were varied to provide similar amounts of feed produced, total grain production did not vary across locations (table 3).

The simulations produced $\mathrm{N}$ and $\mathrm{P}$ balances for all inputs and outputs of the production system. These values varied across locations and fertilization treatments, but average values can be provided. Over the 25 -year simulations, $70 \%$ to $75 \%$ of the applied $\mathrm{N}$ was removed in the crop, with the remainder lost to the environment. Of the total loss, $15 \%$ to $17 \%$ was volatilized as $\mathrm{NH}_{3}, 3 \%$ to $7 \%$ was leached to groundwater, $1 \%$ to $2 \%$ was lost as $\mathrm{N}_{2} \mathrm{O}, 4 \%$ to $6 \%$ was lost as NOx and $\mathrm{N}_{2}$, and less than $1 \%$ was lost in surface runoff. When manure was applied, $70 \%$ to $80 \%$ of the applied $\mathrm{P}$ was

Table 2. Comparison of average observed and simulated emissions for four fertilization treatments of corn in three locations across the Northern Great Plains region. Asterisks (*) indicate a significant difference between observed and simulated data using paired t-test $(\mathrm{p}<0.01)$.

\begin{tabular}{|c|c|c|c|c|c|c|}
\hline \multirow{2}{*}{$\begin{array}{c}\text { Location and } \\
\text { Fertilization Treatment }\end{array}$} & \multicolumn{2}{|c|}{$\begin{array}{c}\text { Methane } \\
\left(\mathrm{g} \mathrm{CH}_{4} \mathrm{ha}^{-1} \mathrm{~h}^{-1}\right)\end{array}$} & \multicolumn{2}{|c|}{$\begin{array}{c}\text { Ammonia } \\
\left(\mathrm{g} \mathrm{NH}_{3} \mathrm{ha}^{-1} \mathrm{~h}^{-1}\right)\end{array}$} & \multicolumn{2}{|c|}{$\begin{array}{l}\text { Nitrous Oxide } \\
\left(\mathrm{g} \mathrm{N}_{2} \mathrm{O} \mathrm{ha}^{-1} \mathrm{~h}^{-1}\right)\end{array}$} \\
\hline & Observed & Simulated & Observed & Simulated & Observed & Simulated \\
\hline \multicolumn{7}{|l|}{ North Dakota } \\
\hline No fertilization & -0.02 & 0.00 & 5.7 & $1.9 *$ & 0.20 & 0.32 \\
\hline Urea fertilizer & -0.01 & 0.00 & 11.5 & 10.6 & 0.64 & 1.54 \\
\hline Manure & 0.08 & 0.11 & 12.5 & 15.0 & 0.57 & 0.90 \\
\hline Manure with bedding & 0.10 & 0.11 & 11.2 & 14.0 & 0.54 & 0.89 \\
\hline \multicolumn{7}{|l|}{ South Dakota } \\
\hline No fertilization & -0.17 & 0.00 & 1.7 & 1.8 & 0.60 & 0.38 \\
\hline Urea fertilizer & -0.01 & 0.00 & 2.7 & $7.0^{*}$ & 1.28 & 0.92 \\
\hline Manure & 0.00 & 0.01 & 2.0 & 4.2 & 0.56 & 0.72 \\
\hline Manure with bedding & 0.05 & 0.01 & 4.1 & 4.2 & 1.19 & 0.72 \\
\hline \multicolumn{7}{|l|}{ Nebraska } \\
\hline No fertilization & 0.38 & $0.00^{*}$ & 0.59 & 0.58 & 0.47 & 0.10 \\
\hline Urea fertilizer & 0.34 & $0.00 *$ & 0.84 & $5.73^{*}$ & 0.55 & 0.61 \\
\hline Manure & 0.38 & $0.00 *$ & 0.59 & $1.27 *$ & 0.79 & 0.52 \\
\hline Manure with bedding & 0.31 & $0.00^{*}$ & 0.63 & $1.27 *$ & 0.75 & 0.52 \\
\hline \multicolumn{7}{|l|}{ All locations } \\
\hline No fertilization & 0.10 & $0.00 *$ & 2.98 & $1.39 *$ & 0.39 & 0.26 \\
\hline Urea fertilizer & 0.13 & $0.00 *$ & 5.72 & $8.39 *$ & 0.73 & 1.28 \\
\hline Manure & 0.14 & $0.05^{*}$ & 6.33 & 7.64 & 0.73 & 0.86 \\
\hline Manure with bedding & 0.18 & $0.05^{*}$ & 5.34 & 7.21 & 0.83 & 0.87 \\
\hline
\end{tabular}


Table 3. Fertilization treatment effects on simulated annual production and environmental impacts of corn produced to feed 2,000 finishing cattle at three locations in the U.S. Northern Great Plains region under recent and projected future climate. ${ }^{\text {|a] }}$

\begin{tabular}{|c|c|c|c|c|c|c|c|}
\hline \multirow[b]{2}{*}{ Location and } & \multirow[b]{3}{*}{ Unit } & \multicolumn{3}{|c|}{ Recent Climate (1990-2015) } & \multicolumn{3}{|c|}{ Projected Climate (2040-2065) } \\
\hline & & Open Lot & Bedded & Inorganic & Open Lot & Bedded & Inorganic \\
\hline Production or Loss Parameter & & Manure & Manure & Fertilizer & Manure & Manure & Fertilizer \\
\hline \multicolumn{8}{|l|}{ Carrington, North Dakota } \\
\hline Average annual temperature & ${ }^{\circ} \mathrm{C}$ & $4.7 \mathrm{f}$ & $4.7 \mathrm{f}$ & $4.7 \mathrm{f}$ & $7.6 \mathrm{~d}$ & $7.6 \mathrm{~d}$ & $7.6 \mathrm{~d}$ \\
\hline Average annual precipitation & $\mathrm{mm}$ & $481 \mathrm{~d}$ & $481 \mathrm{~d}$ & $481 \mathrm{~d}$ & $514 \mathrm{dc}$ & $514 \mathrm{dc}$ & $514 \mathrm{dc}$ \\
\hline Grain production & $\mathrm{t} \mathrm{DM}$ & $1740 \mathrm{a}$ & $1712 \mathrm{a}$ & $1766 \mathrm{a}$ & $1778 \mathrm{a}$ & $1766 \mathrm{a}$ & $1811 \mathrm{a}$ \\
\hline Ammonia emission & $\mathrm{kg} \mathrm{N} \mathrm{ha}^{-1}$ & $14.0 \mathrm{i}$ & $21.3 \mathrm{gh}$ & $22.3 \mathrm{gh}$ & $15.3 \mathrm{i}$ & $24.6 \mathrm{ef}$ & $30.2 \mathrm{~d}$ \\
\hline Nitrate leaching & $\mathrm{kg} \mathrm{N} \mathrm{ha}^{-1}$ & $1.91 \mathrm{e}$ & $1.71 \mathrm{e}$ & $1.83 \mathrm{e}$ & $5.38 \mathrm{de}$ & $4.74 \mathrm{de}$ & $5.24 \mathrm{de}$ \\
\hline Denitrification $^{[\mathrm{b}]}$ & $\mathrm{kg} \mathrm{N} \mathrm{ha}^{-1}$ & 10.9 ef & $11.9 \mathrm{~d}$ & $11.5 \mathrm{de}$ & $10.2 \mathrm{gh}$ & $10.8 \mathrm{efg}$ & $10.8 \mathrm{fg}$ \\
\hline Runoff N & $\mathrm{kg} \mathrm{N} \mathrm{ha}^{-1}$ & 1.31 defgh & $1.53 \mathrm{cde}$ & 1.42 cdefg & $1.20 \mathrm{efgh}$ & $1.45 \mathrm{cdef}$ & 1.32 cdefgh \\
\hline Soluble runoff $\mathrm{P}$ & $\mathrm{g} \mathrm{P} \mathrm{ha}^{-1}$ & 156 efg & 194 ef & $42 \mathrm{~h}$ & $314 \mathrm{~d}$ & 246 de & $55 \mathrm{~h}$ \\
\hline Sediment runoff $\mathrm{P}$ & $\mathrm{g} \mathrm{P} \mathrm{ha}^{-1}$ & $526 \mathrm{de}$ & $975 \mathrm{bc}$ & 503 de & 586 ed & $1195 \mathrm{ab}$ & $666 \mathrm{~d}$ \\
\hline Sediment erosion & $\mathrm{kg} \mathrm{ha}^{-1}$ & 1009 ef & $2111 \mathrm{~cd}$ & $978 \mathrm{f}$ & 1030 ef & $2604 \mathrm{c}$ & 1322 def \\
\hline Energy use & $\mathrm{MJ} \mathrm{kg}^{-1} \mathrm{DM}$ & $2.43 \mathrm{fgh}$ & 2.52 efgh & $3.85 \mathrm{abcd}$ & 2.73 efgh & $2.81 \mathrm{efg}$ & $4.14 \mathrm{ab}$ \\
\hline Greenhouse gas emission & $\mathrm{kg} \mathrm{CO}_{2} \mathrm{e} \mathrm{kg}^{-1} \mathrm{DM}$ & $0.28 \mathrm{ef}$ & $0.31 \mathrm{cdef}$ & $0.38 \mathrm{abc}$ & 0.29 edf & 0.31 cdef & $0.40 \mathrm{abc}$ \\
\hline \multicolumn{8}{|l|}{ Watertown, South Dakota } \\
\hline Average annual temperature & ${ }^{\circ} \mathrm{C}$ & $6.5 \mathrm{e}$ & $6.5 \mathrm{e}$ & $6.5 \mathrm{e}$ & $9.4 \mathrm{c}$ & $9.4 \mathrm{c}$ & $9.4 \mathrm{c}$ \\
\hline Average annual precipitation & $\mathrm{mm}$ & $555 \mathrm{bc}$ & $555 \mathrm{bc}$ & $555 \mathrm{bc}$ & $583 \mathrm{bc}$ & $583 \mathrm{bc}$ & $583 \mathrm{bc}$ \\
\hline Grain production & t DM & $1740 \mathrm{a}$ & $1701 \mathrm{a}$ & $1744 \mathrm{a}$ & 1853 a & $1837 \mathrm{a}$ & $1872 \mathrm{a}$ \\
\hline Ammonia emission & $\mathrm{kg} \mathrm{N} \mathrm{ha}^{-1}$ & $14.0 \mathrm{i}$ & $23.8 \mathrm{fe}$ & $23.2 \mathrm{fgh}$ & $15.1 \mathrm{i}$ & $25.9 \mathrm{e}$ & $30.0 \mathrm{~d}$ \\
\hline Nitrate leaching & $\mathrm{kg} \mathrm{N} \mathrm{ha}^{-1}$ & 8.0 cde & 7.8 cde & 8.8 bcde & $12.8 \mathrm{abdc}$ & $12.7 \mathrm{abdc}$ & $13.0 \mathrm{abcd}$ \\
\hline Denitrification & $\mathrm{kg} \mathrm{N} \mathrm{ha}^{-1}$ & $8.8 \mathrm{i}$ & $9.7 \mathrm{~h}$ & $8.4 \mathrm{ij}$ & $8.0 \mathrm{j}$ & $8.9 \mathrm{i}$ & $7.8 \mathrm{j}$ \\
\hline Runoff N & $\mathrm{kg} \mathrm{N} \mathrm{ha}^{-1}$ & $0.99 \mathrm{~h}$ & 1.17 efgh & $1.07 \mathrm{fgh}$ & $0.95 \mathrm{~h}$ & 1.17 efgh & $1.01 \mathrm{gh}$ \\
\hline Soluble runoff $\mathrm{P}$ & $\mathrm{g} \mathrm{P} \mathrm{ha}^{-1}$ & $111 \mathrm{fgh}$ & $129 \mathrm{fgh}$ & $42 \mathrm{~h}$ & 179 ef & 202 ef & $64 \mathrm{gh}$ \\
\hline Sediment runoff $\mathrm{P}$ & $\mathrm{g} \mathrm{P} \mathrm{ha}^{-1}$ & $342 \mathrm{e}$ & $631 \mathrm{~d}$ & $325 \mathrm{e}$ & $538 \mathrm{de}$ & $1023 \mathrm{~b}$ & $518 \mathrm{de}$ \\
\hline Sediment erosion & $\mathrm{kg} \mathrm{ha}^{-1}$ & $925 \mathrm{f}$ & 1950 cde & $894 \mathrm{f}$ & 1670 cdef & $3668 \mathrm{~b}$ & 1650 cdef \\
\hline Energy use & $\mathrm{MJ} \mathrm{kg}^{-1} \mathrm{DM}$ & $2.58 \mathrm{efgh}$ & $2.73 \mathrm{efgh}$ & $4.01 \mathrm{abc}$ & $2.83 \mathrm{efg}$ & $3.09 \mathrm{edf}$ & $4.22 \mathrm{a}$ \\
\hline Greenhouse gas emission & $\mathrm{kg} \mathrm{CO}_{2} \mathrm{e} \mathrm{kg}^{-1} \mathrm{DM}$ & 0.33 bcdef & $0.37 \mathrm{abcd}$ & $0.43 \mathrm{a}$ & 0.34 abcde & $0.40 \mathrm{ab}$ & $0.43 \mathrm{a}$ \\
\hline \multicolumn{8}{|l|}{ Grand Island, Nebraska } \\
\hline Average annual temperature & ${ }^{\circ} \mathrm{C}$ & $10.7 \mathrm{~b}$ & $10.7 \mathrm{~b}$ & $10.7 \mathrm{~b}$ & $13.5 \mathrm{a}$ & $13.5 \mathrm{a}$ & $13.5 \mathrm{a}$ \\
\hline Average annual precipitation & $\mathrm{mm}$ & $626 \mathrm{ab}$ & $626 \mathrm{ab}$ & $626 \mathrm{ab}$ & $655 \mathrm{a}$ & $655 \mathrm{a}$ & $655 \mathrm{a}$ \\
\hline Grain production & t DM & $1737 \mathrm{a}$ & $1758 \mathrm{a}$ & $1738 \mathrm{a}$ & $1645 \mathrm{a}$ & $1673 \mathrm{a}$ & $1656 \mathrm{a}$ \\
\hline Ammonia emission & $\mathrm{kg} \mathrm{N} \mathrm{ha}^{-1}$ & $23.2 \mathrm{fgh}$ & $46.6 \mathrm{c}$ & $46.0 \mathrm{c}$ & 24.7 ef & $49.3 \mathrm{~b}$ & $55.8 \mathrm{a}$ \\
\hline Nitrate leaching & $\mathrm{kg} \mathrm{N} \mathrm{ha}^{-1}$ & $17.1 \mathrm{ba}$ & $19.6 \mathrm{a}$ & $20.0 \mathrm{a}$ & $16.3 \mathrm{bac}$ & $18.5 \mathrm{a}$ & $18.0 \mathrm{a}$ \\
\hline Denitrification & $\mathrm{kg} \mathrm{N} \mathrm{ha}^{-1}$ & $13.4 \mathrm{c}$ & $16.0 \mathrm{a}$ & $13.4 \mathrm{c}$ & $11.9 \mathrm{~d}$ & $14.3 \mathrm{~b}$ & $12.1 \mathrm{~d}$ \\
\hline Runoff N & $\mathrm{kg} \mathrm{N} \mathrm{ha}^{-1}$ & $1.55 \mathrm{cde}$ & $2.02 \mathrm{ab}$ & $1.70 \mathrm{bcd}$ & $1.66 \mathrm{bcd}$ & $2.17 \mathrm{a}$ & $1.73 \mathrm{bc}$ \\
\hline Soluble runoff $\mathrm{P}$ & $\mathrm{g} P \mathrm{ha}^{-1}$ & $433 \mathrm{c}$ & $481 \mathrm{bc}$ & $79 \mathrm{gh}$ & $577 \mathrm{ab}$ & $629 \mathrm{a}$ & $104 \mathrm{fgh}$ \\
\hline Sediment runoff $\mathrm{P}$ & $\mathrm{g} \mathrm{P} \mathrm{ha}^{-1}$ & 564 de & $1142 \mathrm{ab}$ & $508 \mathrm{de}$ & $707 \mathrm{~cd}$ & $1318 \mathrm{a}$ & $636 \mathrm{~d}$ \\
\hline Sediment erosion & $\mathrm{kg} \mathrm{ha}^{-1}$ & 1743 cdef & $4142 \mathrm{ab}$ & 1680 cdef & $2299 \mathrm{c}$ & 4987 a & $2223 \mathrm{~cd}$ \\
\hline Energy use & $\mathrm{MJ} \mathrm{kg}^{-1} \mathrm{DM}$ & $2.10 \mathrm{gh}$ & $2.22 \mathrm{gh}$ & 3.32 bcde & $1.93 \mathrm{~h}$ & $2.02 \mathrm{gh}$ & $3.23 \mathrm{cdef}$ \\
\hline Greenhouse gas emission & $\mathrm{kg} \mathrm{CO}_{2} \mathrm{e} \mathrm{kg}^{-1} \mathrm{DM}$ & $0.27 \mathrm{ef}$ & $0.31 \mathrm{cdef}$ & 0.35 abcde & $0.25 \mathrm{f}$ & $0.29 \mathrm{edf}$ & 0.34 bdcef \\
\hline
\end{tabular}

[a] Means followed by different letters are significantly different across fertilization treatments, climates, and locations ( $\mathrm{p}=0.05)$.

[b] Denitrification includes $\mathrm{N}_{2} \mathrm{O}, \mathrm{NOx}$, and $\mathrm{N}_{2}$ emissions from both nitrification and denitrification processes.

removed in the crop, with most of the remainder left to accumulate in the soil. With the use of inorganic fertilizer, a 25 -year balance was maintained in the soil. Annual loss of $\mathrm{P}$ was about $2 \%$, with most in the sediment-bound form.

The most consistent and perhaps most important difference among the fertilization treatments was in the $\mathrm{NH}_{3}$ emission (table 3, fig. 3). Due to the warmer climate, $\mathrm{NH}_{3}$ emission was greater in Nebraska than in the Dakotas. At all locations, $\mathrm{NH}_{3}$ emission was greater following application of bedded pack manure compared to open lot manure $(\mathrm{p}<0.05)$. This occurred because more $\mathrm{N}$ was retained in the manure pack. More of the $\mathrm{N}$ was also in an ammonium form, as found in the observed data (Niraula et al., 2018; Mehata et al., 2019). On an open lot, up to half of the excreted manure $\mathrm{N}$ transforms to ammonium and is volatilized as $\mathrm{NH}_{3}$ (Todd et al., 2011). Thus, less is available in an ammonium form when applied, with less potential for loss from the field surface. For the urea treatment, $\mathrm{NH}_{3}$ emission was greater than that following feedlot manure application and similar to that of bedded pack manure at each location $(\mathrm{p}<0.05)$.
The amount of $\mathrm{N}$ lost by leaching varied across locations, with the least in North Dakota and the greatest in Nebraska ( $p<0.05$, table 3 ). The amount leached is predicted in the IFSM as that moving through the soil profile to a depth below the root zone (1 $\mathrm{m}$ for a corn crop; Rotz et al., 2018). Differences in the amount leached were driven by differences in precipitation and soil texture. The lowest precipitation occurred in North Dakota, and the greatest occurred in Nebraska. Soil clay content varied, with the greatest in North Dakota and the least in Nebraska. The use of irrigation in Nebraska also contributed to greater leaching of soil moisture and nutrients. Leached $\mathrm{N}$ in the form of nitrate was similar among fertilization treatments at each location $(p>0.05$, table 3).

Nitrification and denitrification losses include $\mathrm{N}_{2} \mathrm{O}$ and NOx emissions from the soil following fertilization treatments (Waldrip et al., 2014). For simplicity in this article, we include emissions from nitrification in the term denitrification. This total loss was sensitive to the soil clay content and moisture content. There were no large differences in denitrification losses across locations, but the greater clay 


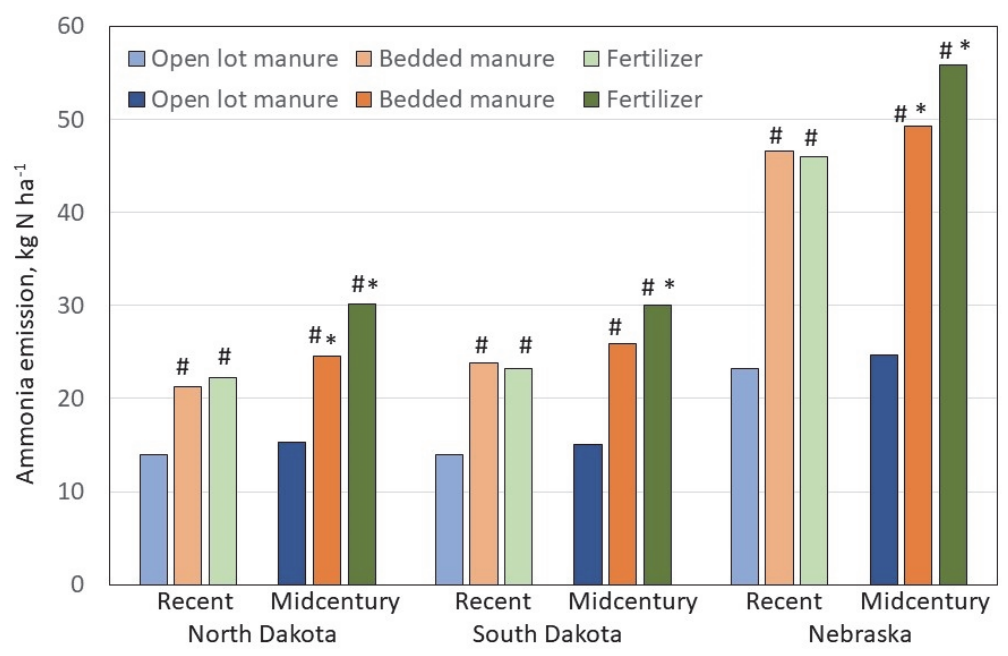

Figure 3. Simulated ammonia emission $\left(\mathrm{kg} \mathrm{N} \mathrm{ha}^{-1}\right)$ following three fertilization options on corn farms in each state for recent and midcentury climate (\# indicates significant difference from open lot manure, and * indicates significant difference due to climate change, $p<0.05$ ).

content in the North Dakota soil and the irrigated loam soil in Nebraska caused slightly greater emissions compared to South Dakota (table 3, fig. 4). Denitrification loss was a little greater with bedded pack manure compared to open lot manure $(\mathrm{p}<0.05)$. Like $\mathrm{NH}_{3}$ emissions, this primarily occurred due to greater $\mathrm{N}$ retention and application with bedded pack manure. Use of urea fertilizer produced similar denitrification loss as the open lot manure treatment in all three locations $(\mathrm{p}<0.05)$.

Simulated runoff losses of $\mathrm{N}$ were small and just a little less in South Dakota compared to the other locations (table 3). There was a trend toward greater losses with the use of bedded pack manure, but the difference was significant only in Nebraska. Due to the removal of a portion of the stover for use as bedding material, there was less ground cover and greater potential for runoff. This same effect was found for predicted sediment erosion and sediment-bound $\mathrm{P}$ runoff ( $\mathrm{p}<0.05$; table 3 ). Runoff of soluble $\mathrm{P}$ was similar between the two manure treatments at each location (table 3 , fig. 5). With the use of incorporated inorganic fertilizers, soluble $\mathrm{P}$ loss was much less than that following manure application $(\mathrm{p}<0.05)$, and predicted sediment erosion and sediment-bound $\mathrm{P}$ losses were similar to those from the manure without bedding (fig. 6).

The farm-gate life cycle assessment showed similar energy consumption trends across locations. The bedded pack manure system showed a trend toward greater energy use compared to the open lot system (table 3). The harvest and handling of the stover for bedding and the handling of a greater volume of manure required greater energy input. This was offset by a small reduction in the amount of $\mathrm{N}$ fertilizer required and the energy required to produce that fertilizer. The greatest overall energy input was with the use of inorganic fertilizer. The energy required to produce the N, P, and $\mathrm{K}$ fertilizers was greater than the energy required to handle the manure.

Farm-gate life cycle assessments of these corn production systems produced similar intensities of greenhouse gas emissions across the three locations (table 3). Effects of the fertilization treatments followed the same trends as energy use. With greater energy input and decomposition of the $\mathrm{C}$ in urea, greater $\mathrm{CO}_{2}$ emissions occurred with the inorganic fertilizer treatment. In addition, as discussed above, denitrification emissions were normally greater with the bedded

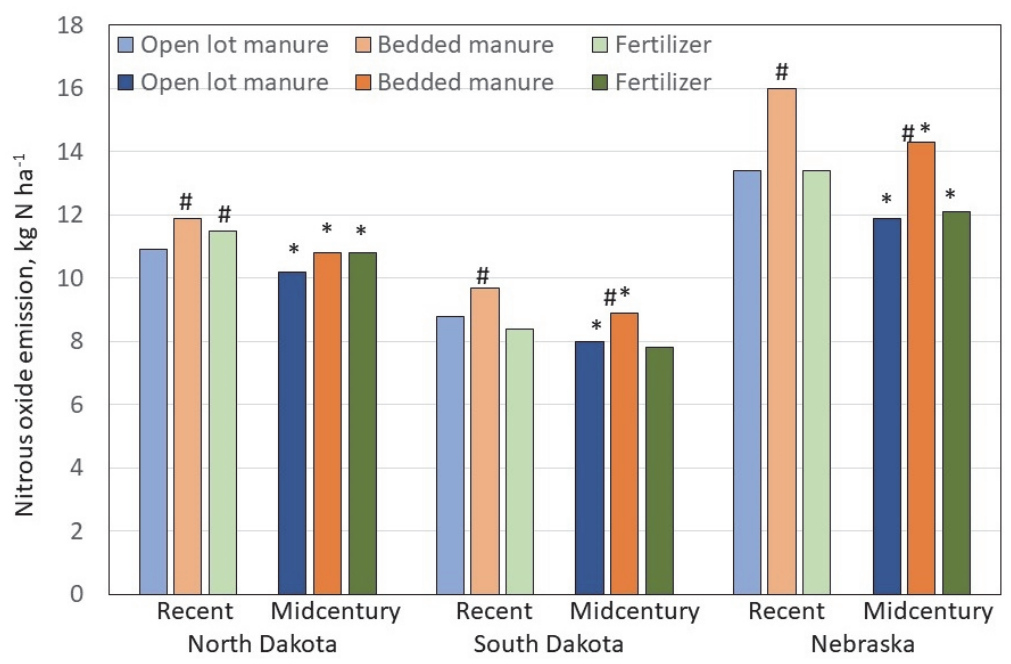

Figure 4. Simulated nitrous oxide emission $\left(\mathrm{kg} \mathrm{N} \mathrm{ha}^{-1}\right)$ following three fertilization options on corn farms in each state for recent and midcentury climate (\# indicates significant difference from open lot manure, and * indicates significant difference due to climate change, $p<0.05$ ). 


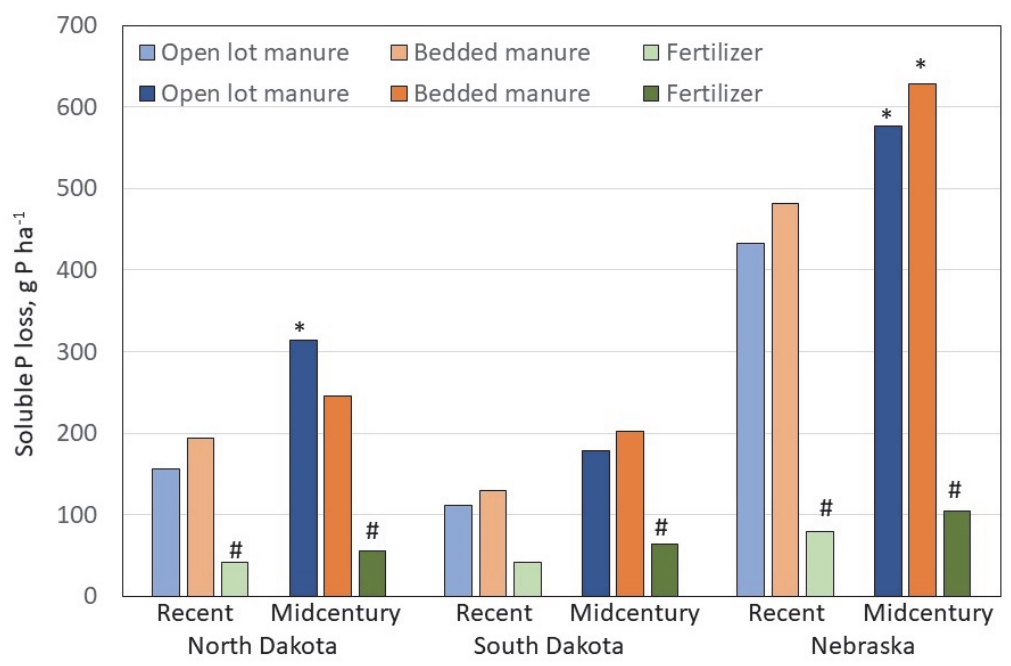

Figure 5. Simulated soluble phosphorus loss $\left(\mathrm{g} \mathrm{P} \mathrm{ha}^{-1}\right)$ following three fertilization options on corn farms in each state for recent and midcentury climate (\# indicates significant difference from open lot manure, and * indicates significant difference due to climate change, $p<0.05$ ).

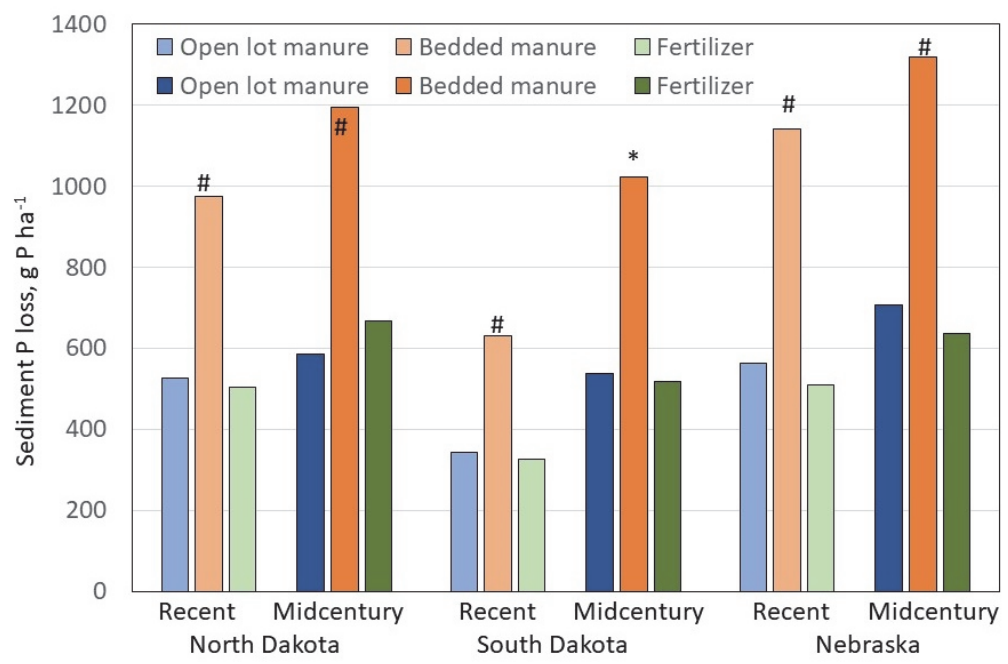

Figure 6. Simulated sediment-bound phosphorus loss $\left(\mathrm{g} \mathrm{P} \mathrm{ha}^{-1}\right)$ following three fertilization options on corn farms in each state for recent and midcentury climate (\# indicates significant difference from open lot manure, and * indicates significant difference due to climate change, $p<0.05$ ).

manure system. At each location, the greenhouse gas emission per unit of feed produced was greater with inorganic fertilizer than with open lot manure, with the use of bedded pack manure falling between those two treatments $(\mathrm{p}<0.05$, table 3).

\section{Production Systems with Midcentury Climate}

The simulations of the alternative strategies using projected climate data illustrated the effects of projected increases in ambient temperature, precipitation, and atmospheric $\mathrm{CO}_{2}$ level on feed production and environmental impacts. For each location and averaged over the nine GCMs and 25-year future period, annual ambient temperature was projected to increase by about $2.9^{\circ} \mathrm{C}$ relative to the recent climate period (table 3 ). Projected changes in annual precipitation were inconsistent among the climate models. Of the nine GCMs, five or six predicted increases in precipitation, two or three predicted decreases, and one showed little change between recent and midcentury climates at each location. Although there was a small increase in precipitation averaged over all models, this increase was not significant at any of the locations. Atmospheric $\mathrm{CO}_{2}$ levels averaged $372 \mathrm{ppm}$ for $1990-2015$, and this increased to $550 \mathrm{ppm}$ for 2040-2065. Increased atmospheric $\mathrm{CO}_{2}$ concentration stimulates $\mathrm{C}$ fixation and plant growth; however, increased yield due to $\mathrm{CO}_{2}$ enrichment in a $\mathrm{C}_{4}$ plant such as corn may only occur under water-stressed conditions (Hatfield and Dold, 2019). In our simulations, moisture stress often occurred in the Dakotas but not in the irrigated conditions of Nebraska, where we assumed adequate water would be available in the future for irrigation.

For our series of simulations, projected climate change did not significantly affect corn grain yield and total production, but there was a trend toward a small increase in production in the Dakotas and a small decrease in Nebraska (table 3). Grain production was also not affected by fertilization treatment under the future climate. The climate effect on grain yield was likely due to offsetting effects. With increased ambient temperature, evapotranspiration increased, which reduced water use efficiency and created greater stress 
on growth. For future simulations in Nebraska, maximum annual irrigation use was set high enough to offset increases in evapotranspiration. Increased summer temperatures may also reduce pollination and grain development (Prasad et al., 2019). These climate effects interact with any stimulation of growth due to greater $\mathrm{CO}_{2}$ concentration in the atmosphere (Hatfield and Dold, 2019).

Projected changes in climate had variable effects on nutrient losses. Ammonia emissions following bedded manure and urea fertilizer treatments increased, with little change in the emissions from open lot manure ( $p<0.05$, fig. 3 ). Because most of the ammonium $\mathrm{N}$ is lost on the open lot, field losses were not affected by the warmer temperatures. As with recent climate, the greatest emission occurred in the warmer climate of Nebraska, with similar emissions in the Dakotas. By midcentury, $\mathrm{NH}_{3}$ emission following urea fertilizer application increased by $20 \%$ to $35 \%$ at the three locations (table 3, fig. 3). These influences of climate were due to the form of $\mathrm{N}$ applied. Most of the ammonium $\mathrm{N}$ in manure was volatilized prior to field application, while essentially all the urea $\mathrm{N}$ in fertilizer hydrolyzes to an ammonium form in the soil. Ammonium $\mathrm{N}$ readily transforms to ammonia, and increasing temperature drives increases in emission (Rotz et al., 2014).

Nitrate leaching losses by midcentury were similar to those from recent climate, with the greatest loss in Nebraska and the least loss in North Dakota (table 3). There was a trend toward greater leaching losses by midcentury in the Dakotas, but the difference was not significant due to the large variation in predictions among climate models. Leaching losses were similar among the fertilization treatments at each location.

Compared to recent climate, denitrification losses of $\mathrm{N}$ decreased by about $9 \%$ across treatments and locations, but this decrease was not always significant (table 3, fig. 4). As with recent climate, denitrification losses were greatest in Nebraska and least in South Dakota. The greatest emission was for bedded pack manure in Nebraska, and the lowest was for urea fertilizer in South Dakota. This decrease was primarily driven by increased $\mathrm{NH}_{3}$ emission. With greater loss prior to incorporation, less $\mathrm{N}$ was available for nitrification and denitrification processes in the soil.

At each location, runoff losses of $\mathrm{N}$ were not affected by climate in this series of simulations, with midcentury values similar to those using recent climate (table 3). As with recent climate, $\mathrm{N}$ runoff under future climate tended to be greater with the bedded pack manure system, but this was only significant in Nebraska $(\mathrm{p}<0.05)$. These changes in $\mathrm{N}$ losses were driven by changes in evapotranspiration, precipitation patterns, and irrigation use across locations. Because these simulations pursued an $\mathrm{N}$ balance, there were interactions among the various losses for a given amount of $\mathrm{N}$ applied. For example, if less denitrification occurred, then more $\mathrm{N}$ was available for leaching to groundwater, or with greater $\mathrm{NH}_{3}$ emission, less was potentially lost through other pathways.

Projected changes in $\mathrm{P}$ losses were influenced by changes in precipitation amounts and patterns, which were inconsistent among climate models. Soluble P losses tended to be greater by midcentury at all locations, but the increase was only significant in Nebraska, where midcentury losses were about $30 \%$ greater than those predicted for recent climate (table 3, fig. 5, p <0.05). As would be expected, the effects of climate were similar for erosion of sediment and runoff of sediment-bound P (fig. 6). Losses were greater following use of bedded pack manure at all locations, with significant increases by midcentury in South Dakota and Nebraska $(p<0.05)$. As found in the recent climate simulations, this increase occurred due to the removal of a major portion of the ground cover through harvest of the stover for bedding material.

As found with recent climate, life cycle intensities of energy use and greenhouse gas emission varied across fertilization treatments and locations, but the large variation created by the GCM predictions hid significance for most differences. As with recent climate, the lowest intensities were for open lot manure, and the highest were for inorganic fertilizer. Values were also greater in the Dakotas and least in Nebraska $(\mathrm{p}<0.05)$, primarily due to the greater corn yields obtained with the irrigated crop in Nebraska. An interaction occurred with energy use expressed per unit of feed increasing under future climate in the Dakotas but decreasing in $\mathrm{Ne}$ braska $(p<0.05)$. Greenhouse gas emission intensity showed the same trend, but the changes were normally too small to show significance.

Overall, the effects of projected climate change varied among the three locations. Projected climate affected each production system similarly to the simulation results obtained with recent climate, so differences among the three production systems using different fertilization strategies were similar under recent and midcentury climates. These simulation results are specific to the soil and climate conditions considered; therefore, these results should not be extrapolated to state and regional levels. They provide guidance for what can be expected as the climate in the Northern Great Plains region changes over the next 40 years, but conditions among farms and locations will vary.

\section{CONCLUSIONS}

The Integrated Farm System Model was able to appropriately represent average emission rates of $\mathrm{CH}_{4}, \mathrm{NH}_{3}$, and $\mathrm{N}_{2} \mathrm{O}$ measured over two years following manure and urea fertilizer applications in corn production at three locations across the Northern Great Plains region, supporting the use of the model for simulations of these three pollutants over many years of weather.

Compared to the use of feedlot manure, the use of bedded pack manure generally increased $\mathrm{N}$ loss in corn production because more $\mathrm{N}$ was retained in the manure removed from bedded housing, providing more opportunity for field losses, and sediment erosion and $\mathrm{P}$ runoff were increased by removing a portion of the stover from the field for use as bedding material.

Compared to sole use of inorganic fertilizers, use of cattle manure increased soluble $\mathrm{P}$ loss but reduced farm-gate lifecycle energy use and greenhouse gas emission in corn production. 
Projected climate change by midcentury affected the three production systems using feedlot manure, bedded pack manure, and inorganic fertilizers similarly, so production and environmental differences among the fertilization options were similar under recent and future climates.

\section{ACKNOWLEDGEMENTS}

This work was funded in part by USDA-ARS Project 1902-11130-002-00D: Mitigating emissions and adapting farm systems to climate variability, and by USDA NIFA Grant No. 2015-67020-23453: Process-based nutrient modeling of integrated beef cattle finishing and crop production systems in the Northern Great Plains. The authors thank Kathleen Yeater, Area Statistician of the Plains Area of the USDA-ARS, for her assistance with the statistical analysis.

\section{REFERENCES}

Asem-Hiablie, S., Rotz, C. A., Stout, R., \& Stackhouse-Lawson, K. (2016). Management characteristics of beef cattle production in the Northern Plains and Midwest regions of the United States.

Prof. Animal Sci., 32(6), 736-749.

https://doi.org/10.15232/pas.2016-01539

Battye, R., Battye, W., Overcash, C., \& Fudge, C. (1994).

Development and selection of ammonia emission factors. EPA/600/R-94/190 (NTIS PB95123915). Washington, DC: U.S. Environmental Protection Agency. Retrieved from https://cfpub.epa.gov/si/si_public_record_Report.cfm?Lab=OR D\&dirEntryId $=32762$

Belflower, J. B., Bernard, J. K., Gattie, D. K., Hancock, D. W., Risse, L. M., \& Alan Rotz, C. (2012). A case study of the potential environmental impacts of different dairy production systems in Georgia. Agric. Syst., 108, 84-93. https://doi.org/10.1016/j.agsy.2012.01.005

Chianese, D. S., Rotz, C. A., \& Richard, T. L. (2009c). Simulation of nitrous oxide emissions from dairy farms to assess greenhouse gas reduction strategies. Trans. ASABE, 52(4), 13251335. https://doi.org/10.13031/2013.27782

Chianese, D. S., Rotz, C. A., \& Richard, T. L. (2009a). Whole-farm greenhouse gas emissions: A review with application to a Pennsylvania dairy farm. Appl. Eng. Agric., 25(3), 431-442. https://doi.org/10.13031/2013.26895

Chianese, D. S., Rotz, C. A., \& Richard, T. L. (2009b). Simulation of methane emissions from dairy farms to assess greenhouse gas reduction strategies. Trans. ASABE, 52(4), 1313-1323. https://doi.org/10.13031/2013.27781

Hatfield, J. L., \& Dold, C. (2019). Water-use efficiency: Advances and challenges in a changing climate. Front. Plant Sci., 10, article 103. https://doi.org/10.3389/fpls.2019.00103

IPCC. (2006). Chapter 11: $\mathrm{N}_{2} \mathrm{O}$ emissions from managed soils, and $\mathrm{CO}_{2}$ from lime and urea application. In IPCC guidelines for national greenhouse inventories: Vol. 4. Agriculture, forestry, and other land use. Geneva, Switzerland: IPCC. Retrieved from https://www.ipcc-

nggip.iges.or.jp/public/2006gl/pdf/4_Volume4/V4_11_Ch11_N 2O\&CO2.pdf

IPNI. (2012). 4R plant nutrition: A manual for improving the management of plant nutrition. Norcross, GA: International Plant Nutrition Institute. Retrieved from https://lccn.loc.gov/2013370328

Malique, F., Ke, P., Boettcher, J., Dannenmann, M., \& ButterbachBahl, K. (2019). Plant and soil effects on denitrification potential in agricultural soils. Plant Soil, 439(1), 459-474. https://doi.org/10.1007/s11104-019-04038-5
Mehata, M., Cortus, E., Niraula, S., Spiehs, M. J., Darrington, J., Chatterjee, A., ... Parker, D. B. (2019). Aerial nitrogen fluxes and soil nitrate in response to fall-applied manure and fertilizer applications in eastern South Dakota. Intl. J. Agron., 2019. https://doi.org/10.1155/2019/8572985

Niraula, S., Rahman, S., \& Chatterjee, A. (2018). Temperature response of ammonia and greenhouse gas emission from manure-amended silty clay soil. Acta Agric. Scandinavica, Section B, 68(8), 663-677. https://doi.org/10.1080/09064710.2018.1459822

Niraula, S., Rahman, S., Chatterjee, A., Cortus, E. L., Mehata, M., \& Spiehs, M. J. (2019). Beef manure and urea applied to corn show variable effects on nitrous oxide, methane, carbon dioxide, and ammonia. Agron. J., 111(3), 1448-1467.

Parkin, T. B., \& Venterea, R. T. (2010). Chamber-based trace gas flux measurements. In R. F. Follett (Ed.), Sampling protocols (pp. 3-39). Washington, DC: USDA-ARS Gracenet.

Prasad, R., Gunn, S. K., Rotz, C. A., Karsten, H., Roth, G., Buda, A., \& Stoner, A. M. (2019). Projected climate and agronomic implications for corn production in the northeastern United States. PLoS One, 13(6), e0198623. https://doi.org/10.1371/journal.pone.0198623

Rotz, C. A. (2004). Management to reduce nitrogen losses in animal production. J. Animal Sci., 82(supp. 13), E119-E137.

Rotz, C. A., Asem-Hiablie, S., Place, S., \& Thoma, G. (2019). Environmental footprints of beef cattle production in the United States. Agric. Syst., 169, 1-13. https://doi.org/10.1016/j.agsy.2018.11.005

Rotz, C. A., Corson, M. S., Chianese, D. S., Montes, F., Hafner, S. D., Bonifacio, H. F., \& Coiner, C. U. (2018). Integrated farm system model: Reference manual ver 4.4. University Park, PA: USDA-ARS Pasture Systems and Watershed Management Research Unit. Retrieved from https://www.ars.usda.gov/ARSUserFiles/80700500/Reference\% 20Manual.pdf

Rotz, C. A., Isenberg, B. J., Stackhouse-Lawson, K. R., \& Pollak, E. J. (2013). A simulation-based approach for evaluating and comparing the environmental footprints of beef production systems. J. Animal Sci., 91(11), 5427-5437. https://doi.org/10.2527/jas.2013-6506

Rotz, C. A., Kleinman, P. J. A., Dell, C. J., Veith, T. L., \& Beegle, D. B. (2011). Environmental and economic comparisons of manure application methods in farming systems. J. Environ. Qual., 40(2), 438-448. https://doi.org/10.2134/jeq2010.0063

Rotz, C. A., Montes, F., Hafner, S. D., Heber, A. J., \& Grant, R. H. (2014). Ammonia emission model for whole-farm evaluation of dairy production systems. J. Environ. Qual., 43(4), 1143-1158. https://doi.org/10.2134/jeq2013.04.0121

Rotz, C. A., Roth, G. W., \& Stout, W. L. (2002). Economic and environmental implications of small grain production and use on Pennsylvania dairy farms. Appl. Eng. Agric., 18(4), 417-428. https://doi.org/10.13031/2013.8752

Rotz, C. A., Skinner, R. H., Stoner, A. M. K., \& Hayhoe, K. (2016). Evaluating greenhouse gas mitigation and climate change adaptation in dairy production using farm simulation. Trans. ASABE, 59(6), 1771-1781. https://doi.org/10.13031/trans.59.11594

Sedorovich, D. M., Rotz, C. A., Vadas, P. A., \& Harmel, R. D. (2007). Simulating management effects on phosphorus loss from farming systems. Trans. ASABE, 50(4), 1443-1453. https://doi.org/10.13031/2013.23617

Spiehs, M. J., Cortus, E. L., Rahman, S., Sarker, N., Niraula, S., Mehata, M., ... Parker, D. B. (2020). Ammonia and greenhouse gas emissions from land application of solid beef manure and urea to corn fields in south central Nebraska. ASABE Paper No. 
2000192. St. Joseph, MI: ASABE. https://doi.org/10.13031/aim.202000192

Stoner, A. M. K., Hayhoe, K., Yang, X., \& Wuebbles, D. J. (2013). An asynchronous regional regression model for statistical downscaling of daily climate variables. Intl. J. Climatol., 33(11), 2473-2494. https://doi.org/10.1002/joc.3603

Todd, R. W., Cole, N. A., Rhoades, M. B., Parker, D. B., \& Casey, K. D. (2011). Daily, monthly, seasonal, and annual ammonia emissions from southern High Plains cattle feedyards. $J$. Environ. Qual., 40(4), 1090-1095. https://doi.org/10.2134/jeq2010.0307

USDA-ARS. (2020). The integrated farm system model. University Park, PA: USDA-ARS Pasture Systems and Watershed Management Research Unit. Retrieved from https://www.ars.usda.gov/northeast-area/up$\mathrm{pa} /$ pswmru/docs/integrated-farm-system-model
USDA-NASS. (2019). Quick Stats 2.0. Washington, DC: USDA National Agricultural Statistics Servcice. Retrieved from http://quickstats.nass.usda.gov

Venterea, R. T. (2010). Simplified method for quantifying theoretical underestimation of chamber-based trace gas fluxes. $J$. Environ. Qual., 39(1), 126-135. https://doi.org/10.2134/jeq2009.0231

Venterea, R. T., Petersen, S. O., de Klein, C. A. M., Pedersen, A. R., Noble, A. D. L., Rees, R. M., ... Parkin, T. B. (2020). Global Research Alliance $\mathrm{N}_{2} \mathrm{O}$ chamber methodology guidelines: Flux calculations. J. Environ. Qual., 49(5), 1141-1155. https://doi.org/10.1002/jeq2.20118

Waldrip, H. M., Rotz, C. A., Hafner, S. D., Todd, R. W., \& Cole, N. A. (2014). Process-based modeling of ammonia emission from beef cattle feedyards with the Integrated Farm System Model. $J$. Environ. Qual., 43(4), 1159-1168. https://doi.org/10.2134/jeq2013.09.0354 